\title{
Н.Б. Виноградов
}

Южно-Уральский государственный гуманитарно-педагогический университет просп. Ленина, 69, Челябинск, 454080

E-mail: vinogradov_n@mail.ru

\section{МИФ О ПУТЕШЕСТВИИ ДУШИ И ПОГРЕБАЛЬНЫЕ ПАМЯТНИКИ СИНТАШТИНСКОГО И ПЕТРОВСКОГО ТИПА БРОНЗОВОГО ВЕКА В ЮЖНОМ ЗАУРАЛЬЕ}

Автор предлагает рассматривать погребальный обряд избранных членов синташтинских и петровских общин (кланов) бронзового века Южного Зауралья как своеобразный символический текст, повествующий о путешествии души в загробный мир на погребальной колеснице ведических боговблизнецов - Ашвинов.

Ключевые слова: бронзовый век, Южное Зауралье, колесница, синташтинские и петровские погребения, путешествие души, Ашвины.

\section{Введение}

Вряд ли какой-нибудь серьезный исследователь станет отрицать тот фракт, что люди всегда в своих погребальных обрядах переплетали рациональные санитарно-гигиенические действия с мифологическими представлениями, унаследованными от прежних времен. Погребальный обряд - это знаковая система.

Почему я упоминаю эти самоочевидные факты? Потому что они неоднократно игнорировались коллегами. Интерпретация синташтинских и петровских погребений, относящихся к рубежу третьего и второго тысячелетий до нашей эры и последующих столетий, о которых пойдет речь ниже, представляет собой случай подобного явного недопонимания.

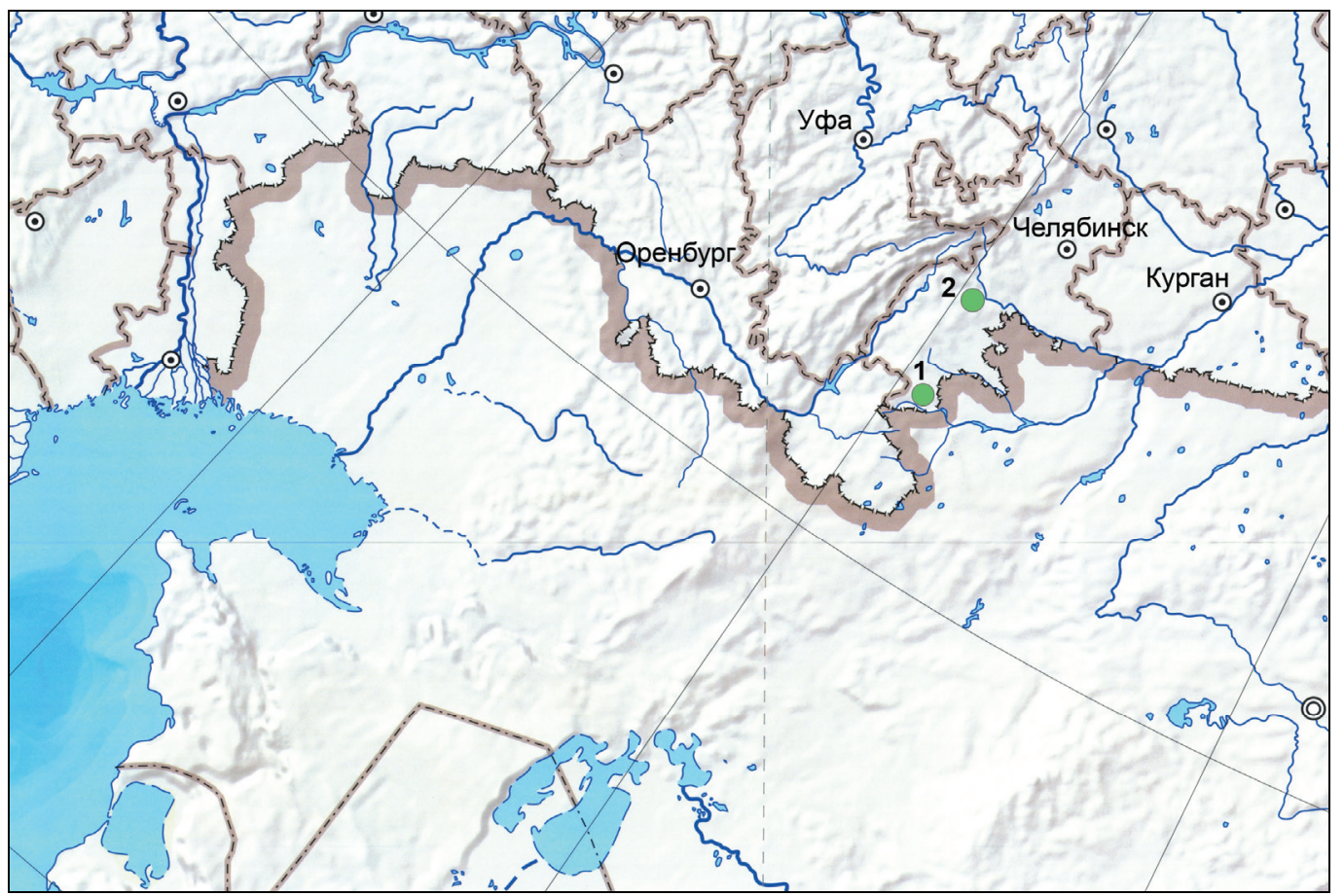

Рис. 1. Локализация Синташтинского могильника и могильника Кривое Озеро в Южном Зауралье: 1 - Синташтинский могильник; 2 - могильник Кривое Озеро.

Fig. 1. Localization of the Sintashta burial ground and the Krivoye Ozero burial ground in the Southern Trans-Urals: 1 - Syntashta burial ground; 2 - Krivoye Ozero burial ground. 
В распоряжении исследователей и сегодня есть лишь более или менее явные следы установки колес в углублениях пола погребальных камер синташтинских и петровских могильников. Однако уже авторы монографии о раскопках эпонимного Синташтинского могильника утверждали, что в погребальную камеру помещались сами колесницы, построенные из тяжелых тесаных досок [Генинг и др., 1992, с. 207-219, рис. 116] (рис. 1). Как и следовало ожидать, критики немедленно возразили им: четверти диаметра колес, помещенных в углубления полов погребальных камер, явно недостаточно для реконструкции колесницы в целом [Littauer, Crouwel, 1996, с. 939] (рис. 2). Тем не менее тезис о том, что синташтинским обществом управляла военная колесничная элита, уже стал стандартной исторической реконструкцией [Ткачев, 2003, с. 85].

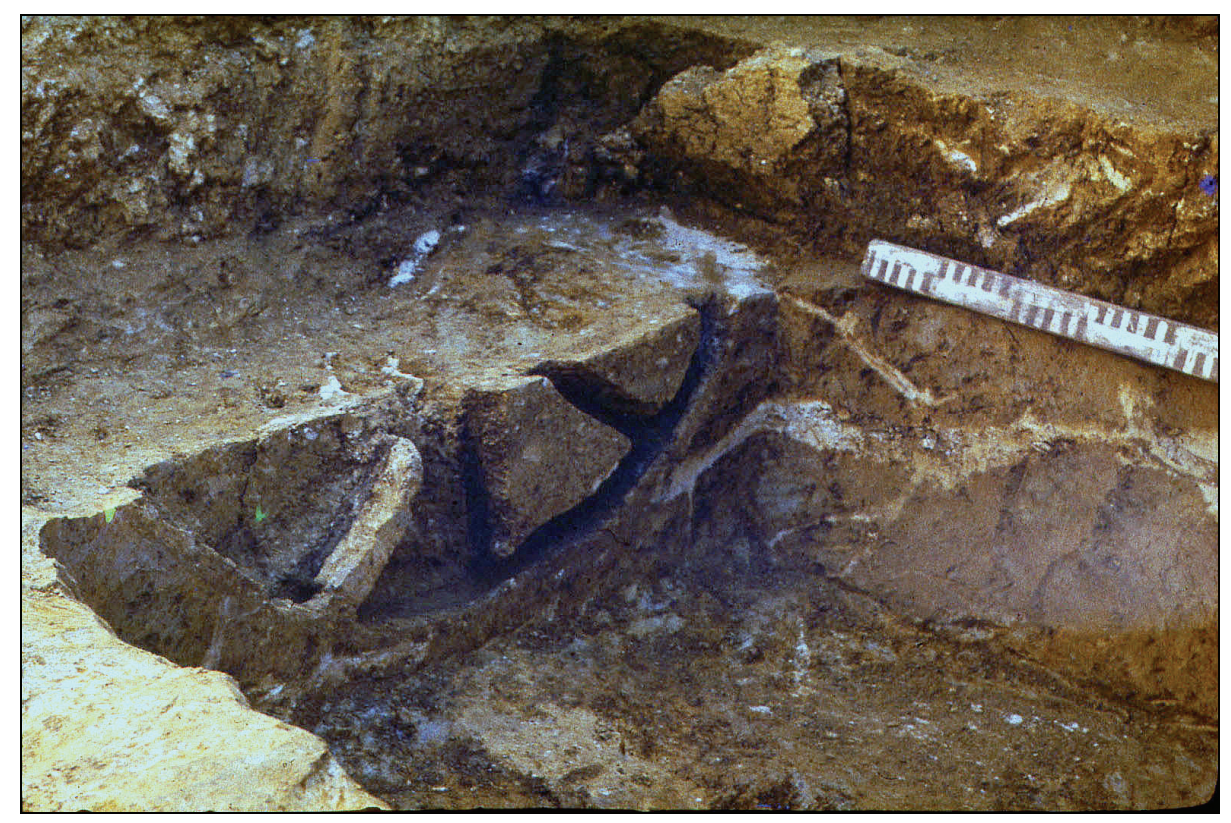

Рис. 2. Синташтинский Большой грунтовый могильник (СМ). Одно из колес имитации погребальной колесницы в яме $30 \mathrm{CM}$. Фото Н. Виноградова.

Fig. 2. Syntashta Large Soil burial ground (CM). One of the wheels of the imitation funeral chariot in the pit 30. Photographer N. Vinogradov.

Абсолютное большинство исследователей и сейчас поддерживает гипотезу о том, что в погребальную камеру здесь помещались именно колесницы, в собранном или разобранном виде, но колесницы. Основным предназначением колесниц, по мнению И.В. Чечушкова, было участие в военных действиях, правда с оговоркой о возможности их использования и в ритуальных действиях [2011, с. 57].

Лишь Д.Г. Зданович и Е.В. Куприянова соглашаются с высказанным мной ранее мнением [Виноградов, 2003, с. 264-265], что, как правило, в могилу помещали не всю колесницу, а лишь ось с колесами [Зданович, Куприянова, 2008, с. 193]. Однако, по мнению тех же авторов, целые костяки коней или их макетные выкладки в синташтинских и петровских гробницах Южного Зауралья и Северного Казахстана есть не что иное, как жертвоприношения, семантика которых связана с индоевропейским мифом о божественных близнецах.

\section{Обсуждение источников. Дискуссия}

Основной причиной моих сомнений первоначально стали параметры реконструируемых коллегами степных колесниц бронзового века Южного Зауралья, в частности ширина колеи, т.е. расстояние между колесами. Опять же коллеги упорно рассматривают расстояние между продольными осями колесных углублений в синташтинских и петровских могилах как ширину колеи реальных колесниц бронзового века.

Возражения были проигнорированы, однако они заслуживают серьезного рассмотрения. В целом они состоят из следующих тезисов:

1. Углубления колес прослеживаются лишь в небольшой части синташтинских или петровских погребений. В Южном Зауралье и Северном Казахстане насчитывается от 20 до 25 таких 


\section{Н.Б. Виноградов}

могил взрослых людей [Чечушков, Епимахов, 2010, с. 191; Чечушков, 2011, с. 57]. Они не обязательно связаны только с экстраординарными личностями - взрослыми мужчинами - воинами.

2. Почти во всех погребениях - за исключением ямы 1 кургана 9 могильника Кривое Озеро какие-либо следы других частей колесницы (ось, кузов, дышло, ярмо и т.д.) отсутствуют.

3. Расстояние между продольными осями колесных углублений скорее было обусловлено шириной деревянной погребальной камеры, а не параметрами реального транспортного средства (рис. 3).

Достаточно заметить, что и сами оппоненты указывают на ширину колеи колесницы из гробницы Тутанхамона (165 см) и ширину колеи колесниц Аньяна (200-210 см) [Чечушков, 2011, c. 61]. Разброс диапазона значений ширины колеи для «колесниц» бронзового века степей Южного Зауралья и Северного Казахстана (по И.В. Чечушкову) - от 95 до 150 см [Там же, с. 60], на наш взгляд, обусловлен не в последнюю очередь именно размерами конкретных погребальных камер. В реальности повозки с подобной шириной колеи будут фатально неустойчивы и склонны к опрокидыванию на поворотах при быстром перемещении.

Таковы основные аргументы, позволяющие утверждать, что в углубления в полу синташтинских и петровских гробниц устанавливались (или укладывались) лишь колеса.

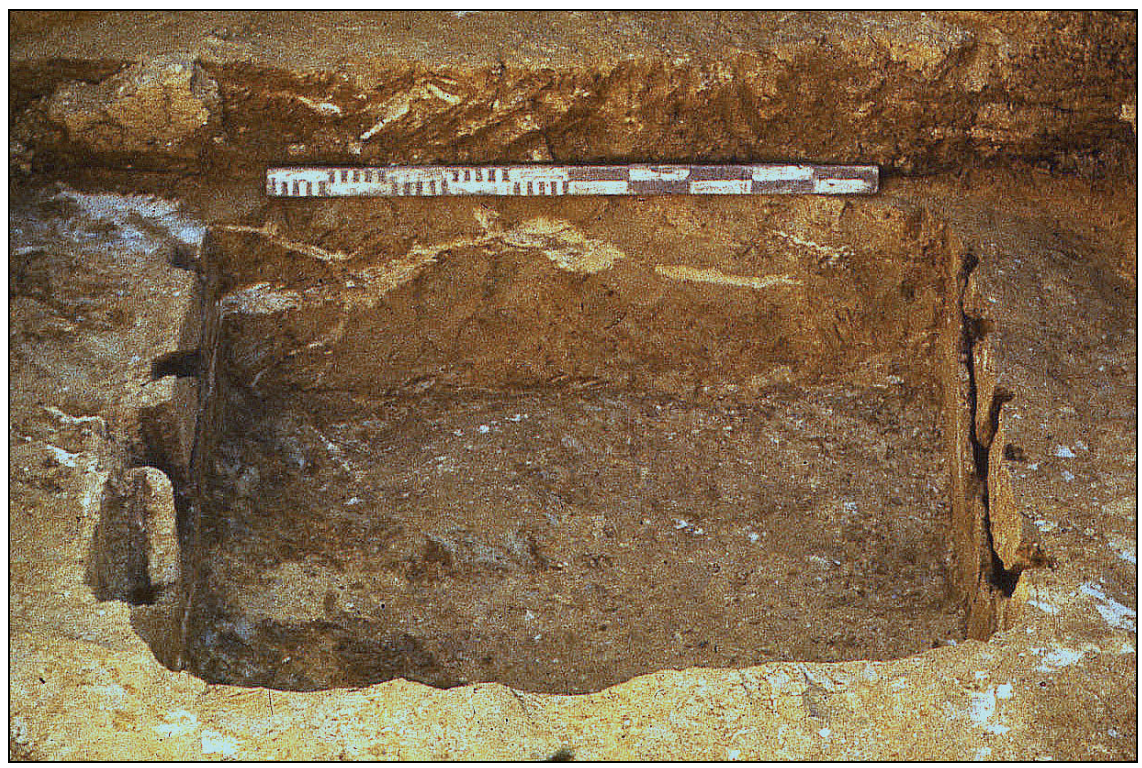

Рис. 3. Остатки двух колес, вкопанных в пол погребальной камеры ямы 30 Синташтинского Большого грунтового могильника (СМ). Фото Н. Виноградова.

Fig. 3. The remains of two wheels dug into the floor of the burial chamber of pit 30 Syntashta Large soil burial ground (CM). Photographer N. Vinogradov.

Колесные углубления и отпечатки нижней четверти диаметра колес в обсуждаемом контексте могут быть скорее интерпретированы как свидетельство существования у синташтинского и петровского населения Южного Урала и Северного Казахстана представлений о мифическом путешествии в загробный мир души некоторых избранных членов рода. Макетная реализация концепции такого «путешествия» впервые археологически зафриксирована в памятниках ямной культурноисторической общности на заре бронзового века [Избицер, 1993]. Она получила развитие в эпоху средней бронзы в культурах катакомбного круга, а позднее распространилась среди больших групп степного населения на рубеже средней и ранней поздней бронзы. Причем не только среди обитателей синташтинских и петровских укрепленных поселений в Южном Зауралье и Северном Казахстане, но и среди населения синхронных групп восточноевропейского степного населения. Угасла эта традиция по не вполне понятным причинам уже в позднем бронзовом веке.

Автор, таким образом, полагает, что в синташтинских, петровских и иных восточноевропейских степных культурах, синхронных с ними, по-видимому, преобладала традиция размещения в погребальной камере именно частей колесницы, особенно колес, а не целых колесниц. Критика М.А. Литтауэр и Дж.Х. Кроуэлла [Littauer, Crouwel, 1996, p. 939], поддержанная Е.Е. Кузьминой [2000, с. 6], как кажется, была правильна и справедлива. 


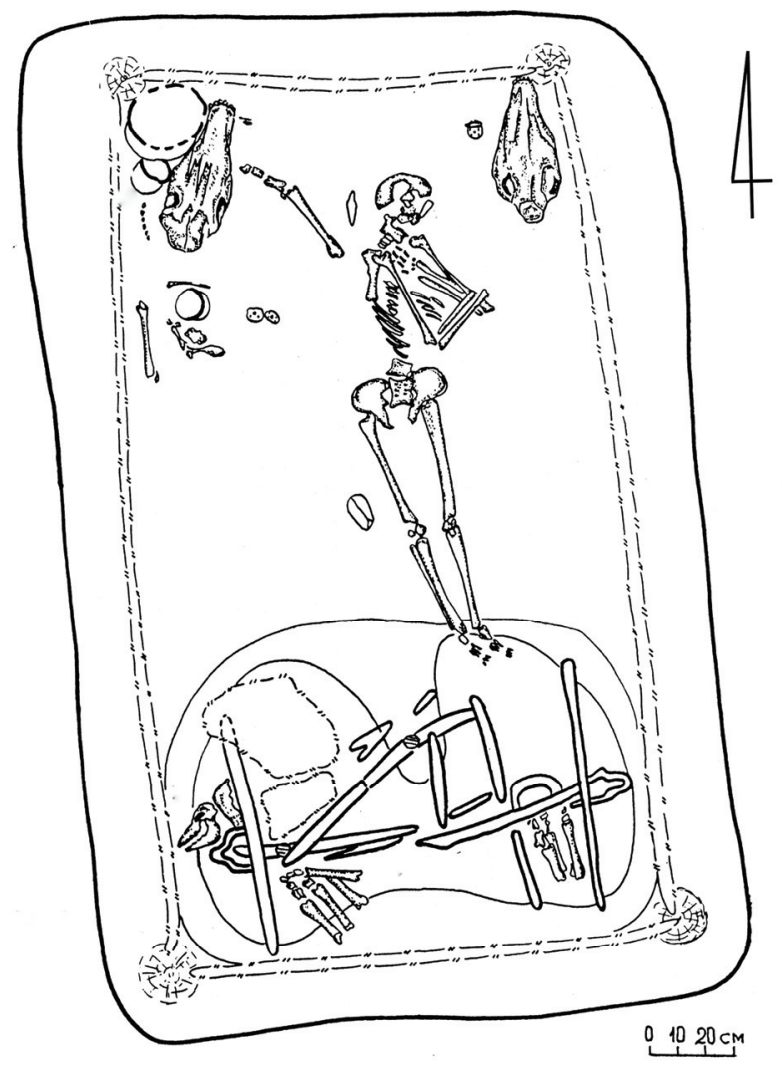

Рис. 4. Могильник Кривое Озеро. Курган 9. Яма 1. Остатки на полу погребальной камеры. Fig. 4. Krivoye Ozero burial site. Kurgan 9. Pit 1. Remains on the floor of the burial chamber.

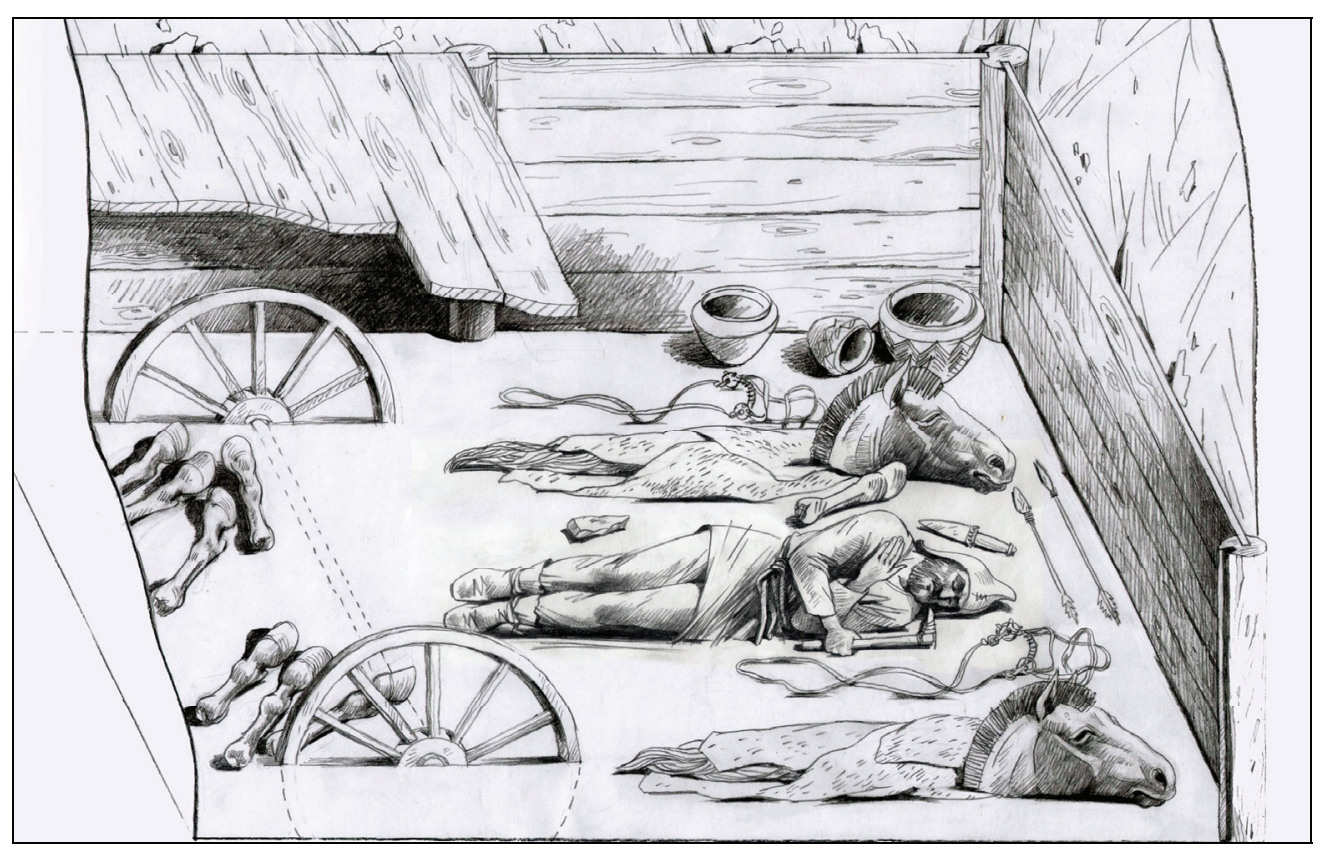

Рис. 5. Могильник Кривое Озеро. Курган 9. Яма 1. Имитация погребальной колесницы. Реконструкция обряда. Художник В. Витлиф. Из фондов ОГБУК «Исторический Музей Южного Урала».

Fig. 5. Krivoye Ozero burial site. Kurgan 9. Pit 1. Imitation of the burial chariot. Reconstruction. Artist V. Witlif. From the collections of the OGBUK Museum of history of the Southern Urals. 


\section{Н.Б. Виноградов}

Наводят на размышления и характеристики самих колесных углублений. Так, в полу погребальной камеры ямы 12 «Большого Синташтинского грунтового могильника» (CM) было обнаружено не менее четырех, возможно, даже пяти колесных углублений. Их можно интерпретировать как углубления для колес [Генинг и др., 1992, с. 162]. Две пары углублений находились в противоположных половинах дна ямы, а пятая - ближе к середине одной из длинных сторон ямы. В этом случае можно говорить о нескольких вариантах решения вопроса. Углубления могли имитировать четырехколесную телегу, что было нормой для предыдущих степных культур раннего и среднего бронзового века. Или же это могли быть две двухколесные повозки, колеса которых располагались в противоположных частях ямы. Или же мы видим здесь редкий случай изменения расположения колес в погребальной камере во время погребальной церемонии.

Еще более загадочным является пример, приведенный раскопками могильника Каменный Амбар 5, где в яме 6 кургана 2 на дне камеры было расчищено только одно колесное углубление [Костюков и др., 1995, с. 162]. В.И. Стесранов и А.В. Епимахов [2006, с. 271] полагают, что во время погребальной церемонии (Малый курган Синташта III) колесница могла быть помещена в погребальную камеру только временно или ее размещение в погребальной камере было лишь имитацией.

\section{Выводы}

По мысли автора, колесные углубления скорее были частью макетного воспроизведения символа - знака повозки, где «кузовом» служила сама деревянная погребальная камера (рис. 4, 5). Автор полагает, что то, что считается коллегами в синташтинских и петровских могильниках колесницами, по-видимому, должно пониматься скорее как часть макета погребальной «повозки», предназначенной для мифического путешествия души, а не реального транспортного средства.

В контексте размышлений о реальности существования у обитателей синташтинских укрепленных поселений мифологических представлений о путешествии души интересны наблюдения за положением рук взрослых людей, погребенных в синташтинских могильниках. В могильнике Кривое Озеро взрослый мужчина, захороненный в яме 1 кургана 9, в правой руке сжимает деревянную рукоять бронзового тесла, а пальцы его левой руки прижаты к груди [Виноградов, 2003, с. 86]. В ямах 3 и 7 кургана 9 того же могильника руки погребенных были сложены вместе, в то время как у взрослого человека, погребенного в яме 3 кургана 10, пальцы рук, согнутых в локтях, симметрично размещены по обе стороны от лица. Представляет интерес положение рук человека, похороненного в яме 6 кургана 10 могильника Кривое Озеро. Правая рука, согнутая в локте, лежит параллельно туловищу, а левая рука явно намеренно касается лица [Там же, c. 149]. Нечто подобное можно наблюдать и в погребении в яме 13 кургана 10 могильника Кривое Озеро, а также в других синташтинских могильниках.

По мнению автора, разнообразие позиций рук, описанное выше, также косвенно подтверждает вероятность существования мифра о путешествии души в погребальной обрядности синташтинского и петровского населения.

Жертвоприношения животных, хорошо известные из обширной литературы, также могут быть упомянуты в подтверждение гипотезы о том, что синташтинский и петровский погребальные обряды отражают представления о путешествии души умершего в загробный мир. Иногда синташтинские гробницы включают целые отсеки, набитые головами, ногами и шкурами жертвенных животных. Жертвоприношения могли совершаться и на перекрытии гробницы или у края могильной ямы (рис. 6). По мнению Е.Е. Кузьминой, конкретные виды животных предназначались в этом случае в качестве жертв конкретным богам [1986, с. 89].

В погребальных обрядах древних народов нет праздных деталей. Каждый элемент обряда имеет свою семантику. Большой вопрос: действительно ли нарочито приостренные шипы костяной пластинки из могильника Каменный Амбар 5 [Епимахов, 2002, с. 42] имитируют роговой псалий? Псалии достаточно известны в синташтинской и петровской погребальной обрядности. Некоторые из них имеют явные признаки длительного износа. Если сосуды с явными следами технологического брака в синташтинских погребениях можно объяснить общими представлениями о «душе вещей» [Виноградов и др., 2017, с. 34, рис. 33] (рис. 7), то обсуждаемая имитация псалиев, возможно, изначально, при изготовлении, предназначалась для сказочно экстремальной ситуации. И этот предмет, видимо, был вплетен в некую конкретику, служил отражением неизвестного мифра, повествующего о путешествии души в мир за гробом. 
Миф о путешествии души и погребальные памятники синташтинского и петровского типа...

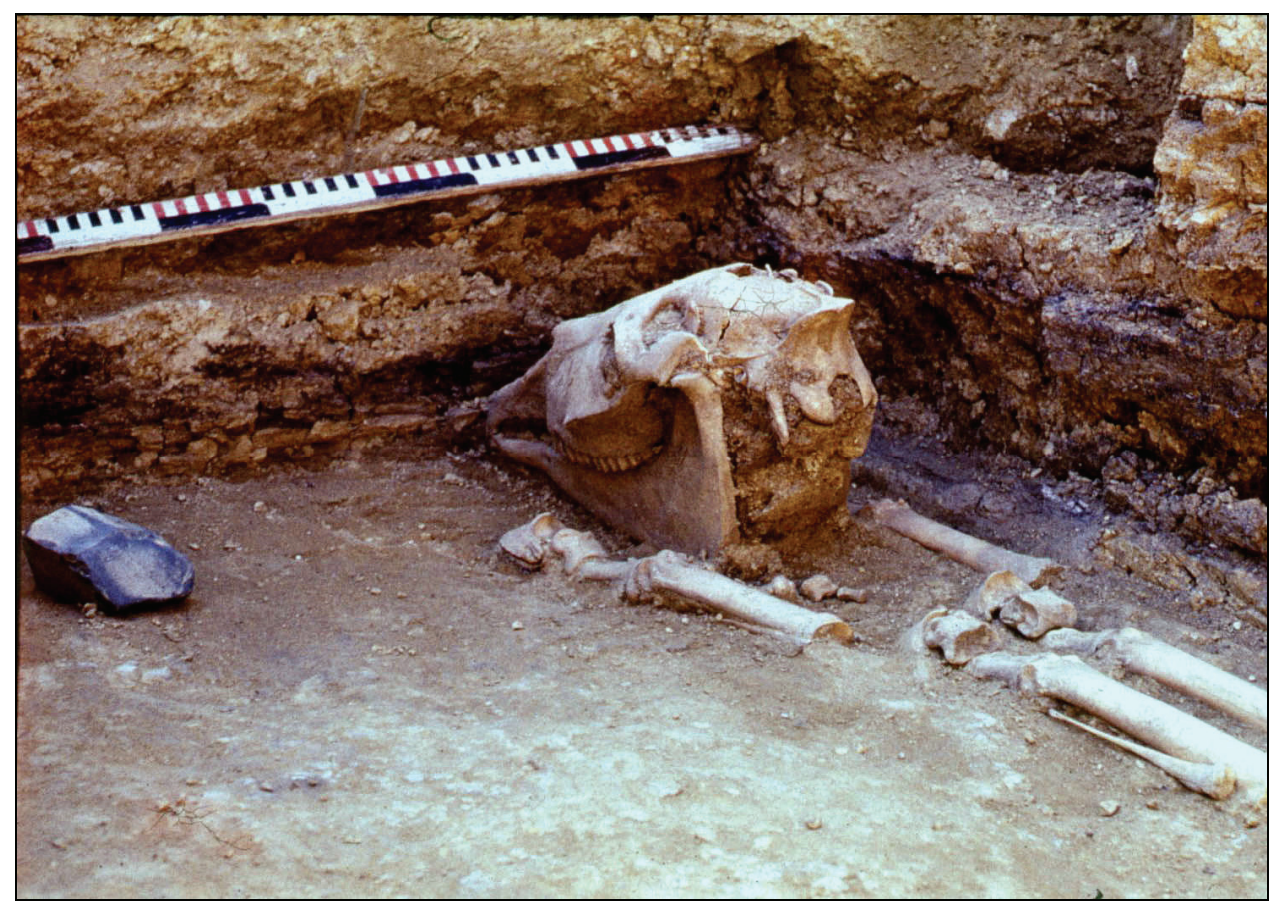

Рис. 6. Синташтинский большой грунтовый могильник (СМ). Яма 30. Выкладка частей туши одного из двух коней. Фото Н. Виноградова.

Fig. 6. Syntashta Large Soil burial ground (CM). Pit 30. Laying out parts of the carcass of one of the two horses. Photographer N. Vinogradov.

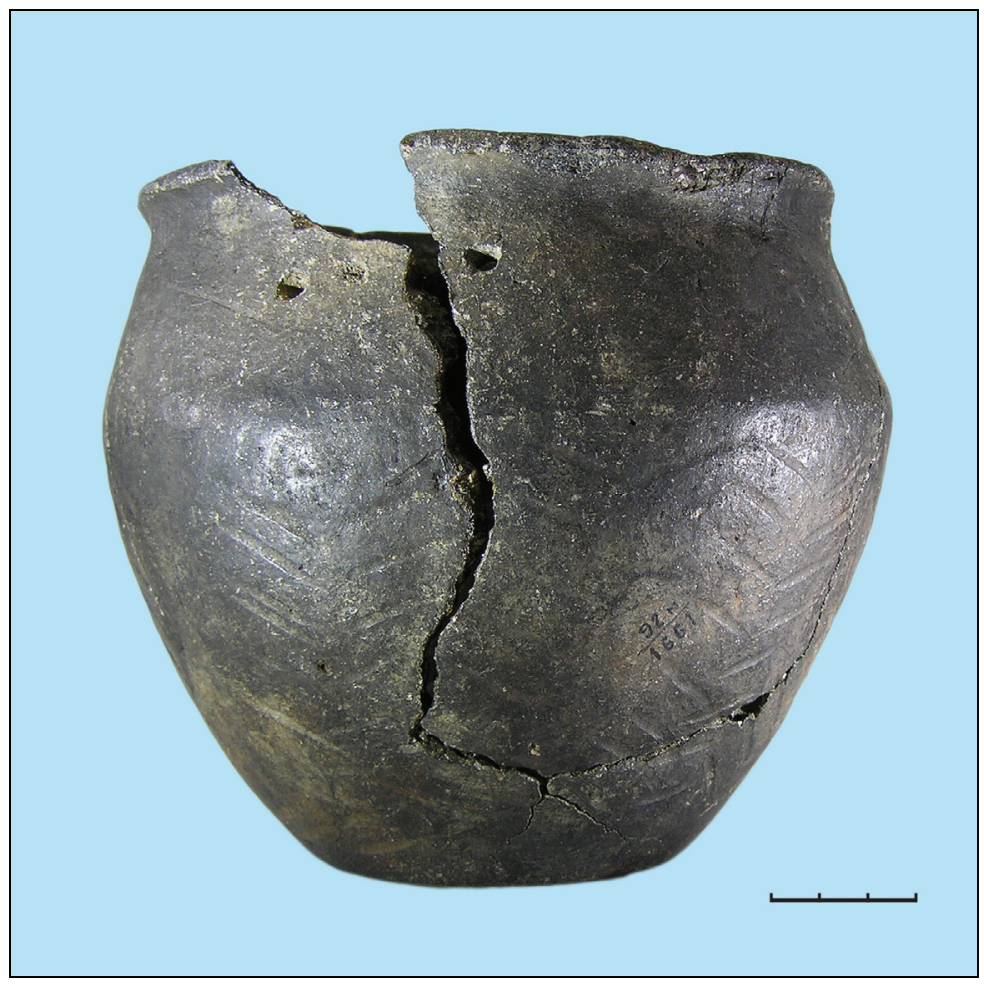

Рис. 7. Могильник Кривое Озеро. Курган 10. Яма 3. Сосуд № 3 со следами повреждения при сушке или обжиге. Фото Н. Виноградова.

Fig. 7. Krivoye Ozero burial site. Kurgan 10. Pit 3. Vessel No. 3 with traces of damage during drying or firing. Photographer N. Vinogradov. 


\section{Н.Б. Виноградов}

Первой заговорила о проблеме, обсуждаемой здесь, в общих чертах Е.Е. Кузьмина [1986, с. 89]. Традиционное мировоззрение многих древних народов содержит представление о мире, отличном от нашего, куда душа уходит после фризической смерти.

Важной среди идей, связанных с этим другим миром, была локализация загробного мира в пространстве. Как правило, это определялось астрономически наблюдаемыми явлениями. В обсуждаемых археологических памятниках ориентировка погребенного головой, вероятнее всего, и указывает на направленность расположения мира загробной жизни. Статистика показывает, что в погребальных обрядах населения синташтинских укрепленных поселений представлены различные стороны горизонта. Вряд ли в пределах индоиранского мира, при отсутствии контролирующих институтов, функционировали единые представления о локализации загробного мира. Е.Е. Кузьмина, в частности, указывает, что «у индийцев “плохой”, опасной стороной считался юг, у иранцев - север» [1986, с. 87]. Предвосхищая возражения критиков, замечу, что в эпонимном Синташтинском могильнике в ориентировке погребенных в гробницах с символическими погребальными повозками более представлен южный сектор небосклона. Однако в целом более распространена ориентировка погребенных именно в северном - северо-западном секторе [Епимахов, 2002, с. 42; Виноградов, 2011, с. 34]. Следует отметить, что в данном контексте речь идет только о захоронениях взрослых людей. Как правило, и погребенные люди, и макетные выкладки коней ориентированы единообразно. В северную сторону, в частности, обращен головой и сам погребенный и головы коней, составляющие часть символической погребальной «колесницы», в известном погребении 1 кургана 9 могильника Кривое Озеро (рис. 4, 5).

Полагаю, что в этом и подобных случаях именно на севере небесной сферы для устроителей погребальной церемонии располагался легендарный авестийский мост Чинват - ворота в загробную жизнь. В астрономическом аспекте северный сектор неба для средних широт - это прежде всего Полярная звезда, созвездия Большой и Малой Медведицы, нашедшие отражение в ведических гимнах. Туда и направлялась символическая повозка погребальных богов Ашвинов с душами избранных по не вполне понятным критериям членов синташтинского общества, запряженная символической парой лошадей [Parpola, 2015, p. 115-129]. А. Парпола полагает, что именно колесница погребальных богов-близнецов Ашвинов доставляет душу умершего в загробный мир (рис. 8).

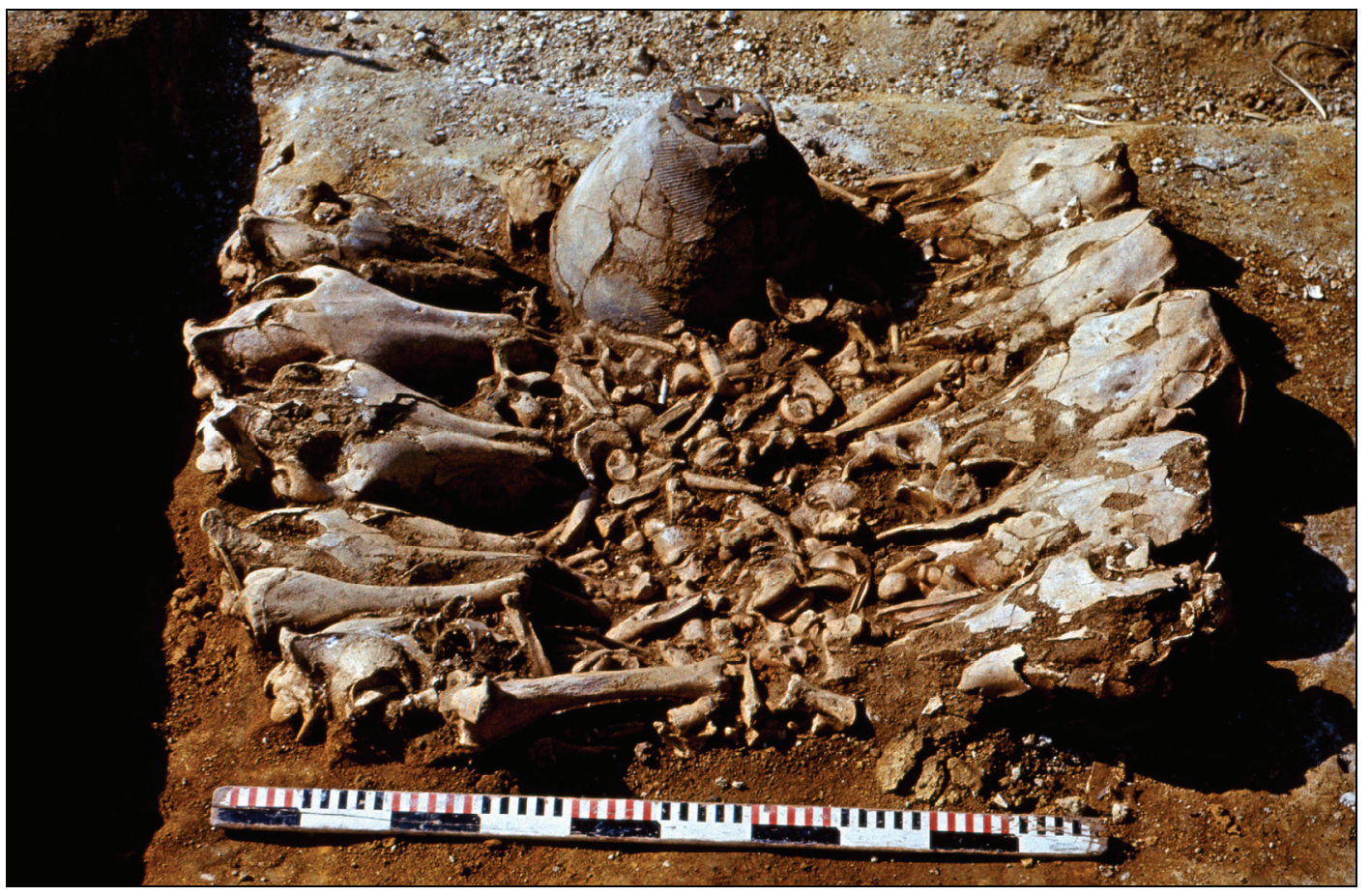

Рис. 8. Синташтинский Большой грунтовый могильник. Жертвенник 1. Фото Н. Виноградова.

Fig. 8. Syntashta Large Soil burial ground (CM). The altar 1. Photographer N. Vinogradov.

Очень жаль, что пока нет данных о масти коней Ашвинов. Но, если и случится определить их масть, скорее всего, один из них окажется черным, а другой - белым. 


\section{Миф о путешествии души и погребальные памятники синташтинского и петровского типа...}

Представления о локализации мира мертвых не были постоянными и изменялись в течение нескольких столетий даже у родственного массива населения - от синташтинского времени до времени классического этапа истории алакульской культуры (керамика с уступчатым плечом, с орнаментацией, разнесенной по двум или трем зонам). Для петровских могильных ям уже доминирует широтная ориентировка, на закат Солнца [Виноградов, 2011, с. 102]. Эти изменения, как кажется, отражают очередную модификацию погребального мифа.

\section{БИБЛИОГРАФИЧЕСКИЙ СПИСОК}

Виноградов Н.Б. Могильник бронзового века Кривое Озеро в Южном Зауралье. Челябинск: Юж.-Урал. кн. изд-во, 2003. 362 с.

Виноградов Н.Б. Степи Южного Урала и Казахстана в первые века II тыс. до н.э.: (Памятники синташтинского и петровского типа). Челябинск: АБРИС, 2011. 175 с.

Виноградов Н.Б., Дегтярева А.Д., Кузьминых С.В., Медведева П.С. Образы эпохи: Могильник бронзового века Кривое Озеро в Южном Зауралье. Челябинск: АБРИС, 2017. 400 с.

Генинг В.Ф., Зданович Г.Б., Генина В.В. Синташта: Археологические памятники арийских племен Урало-Казахстанских степей. Челябинск: Юж.-Урал. кн. изд-во, 1992. Ч. 1. 407 с.

Епимахов А.В. Южное Зауралье в эпоху средней бронзы. Челябинск: Изд-во ЮУрГУ, 2002. 170 с.

Зданович Д.Г., Куприянова Е.В. Парные жертвоприношения лошадей в бронзовом веке в Центральной Евразии: Археология, мифология и ритуал // Происхождение и распространение колесничества. Луганск: Глобус, 2008. С. 188-197.

Избицер Е.В. Погребения с повозками степной полосы Восточной Европы и Северного Кавказа III-II тыс. до. н.э.: Автореферат дис. ... канд. ист. наук. СПб., 1993. 26 с.

Костюков В.П., Епимахов А.В., Нелин Д.В. Новый памятник средней бронзы в Южном Зауралье // Древние индоиранские культуры Волго-Уралья (II тыс. до н.э.). Самара: Изд-во СамГПУ, 1995. С. 156-207.

Кузьмина Е.Е. Древнейшие скотоводы от Урала до Тянь-Шаня. Фрунзе: Илим, 1986. 135 с.

Кузьмина Е.Е. Кони и колесницы Южного Урала и индоевропейские мифы // Проблемы изучения энеолита и бронзового века Южного Урала. Орск: Ин-т Евразийских исслед.: Ин-т степи УрО РАН, 2000. С. 3-9.

Стесранов В.И., Епимахов А.В. Синташтинский III (малый) курган: Некоторые подробности и новые сюжеты // Вопросы археологии Поволжья. Самара: Научно-технический центр, 2006. Вып. 4. С. 263-272.

Ткачев В.В. Погребение архаического лидера эпохи поздней бронзы из могильника Илекшар I в Западном Казахстане // Вопросы истории и археологии Западного Казахстана. Уральск: Западно-Казахстанский центр истории и археологии: Институт истории им. А.Х. Маргулана, 2003. Вып. 2. С. 80-88.

Чечушков И.В. Колесницы евразийских степей эпохи бронзы // Вестник археологии, антропологии и этнографии. 2011. № 2. С. 57-65.

Чечушков И.В., Епимахов А.В. Колесничный комплекс Урало-Казахстанских степей // Кони, колесницы и колесничие степей Евразии. Екатеринбург; Самара; Донецк. 2010. С. 182-230.

Littauer M.A. \& Crouwel J.H. The origin of the true chariot // Antiquity. Vol. 270. 1996.

Parpola A. The Roots of Hinduism. The Early Aryans and the Indus Civilization. Oxford University press, 2015.

N.B. Vinogradov

South Ural State Humanitarian and Pedagogical University prosp. Lenina, 69, Chelyabinsk, 454080, Russian Federation

E-mail: vinogradov_n@mail.ru

\section{The myth of the journey of the soul and Bronze Age funerary sites of the Sintashta and Petrovka type in the Southern Trans-Urals}

The article presents an attempt to interpret the semantics of one of the brightest examples of the burial rite among the pastoral population with high level of metal production, which left the sites of the Sintashta and Petrovka type, localized in the Southern Trans-Urals (Trans-Ural peneplain). They are presently dated to the period between the $21^{\text {st }}$ and $18^{\text {th }} \mathrm{c}$. BC (transitional time from the Middle to Late Bronze Age). Materials from the burial sites (cemeteries of Sintashta and Krivoye Ozero) have been analysed, with direct involvement of the author. The problem appears as follows. The vast majority of researchers believe that within the burial chamber of some Sinthashta and later Petrovka socially significant persons, the chariots were placed, in an assembled or disassembled form, yet chariots. The main purpose of the chariots, in their opinion, was participation in military activities, with a caveat about the possibility of their use in rituals, and that the buried themselves should be recognised as chariot drivers-warriors who ruled the life of communities (clans). The article substantiates the hypothesis of the apparent existence of a tradition in the Sintashta, Petrovka and other synchronous Eastern European steppe cultural formations, of placing in the burial chamber the very parts of a chariot, especially the wheels, and not the whole chariots. The author suggests considering the funeral rite of the chosen members of the Bronze Age Sin- 


\section{Н.Б. Виноградов}

tashta and Petrovka communities (clans) of the Southern Trans-Urals, which involved the use of chariot parts (wheels), as a kind of symbolic text, as a modelled realization of the funeral myth, which tells the story of the journey of the soul to the afterlife on the burial chariot of the Vedic twin gods - Ashwins. The detailed parameters of such models should not be literally correlated with the real transportation means. According to the author, the individuals buried in such tombs were not necessarily chariot drivers-warriors. The paper discusses another important aspect - the localization of the other world for the Bronze Age Sintashta and Petrovka population of the Southern Trans-Urals. According to our observations, the ideas about the localization of the world of the dead were not permanent and could change over several centuries, from the Sintashta period to the time of the classical stage of the history of the Alakul Culture (pottery with a ledge shoulder, with ornamentation spread across two or three zones). The majority of adults in the Sintashta burials with wheel hollows, were orientated with their heads to the northwest sector. Similar was the orientation of symbolic wagons and equally symbolic horses. For alike Petrovka burial sites, the latitudinal orientation already prevailed. These changes, as it appears to the author, reflect modifications of the funeral myth.

Key words: Bronze Age, Southern Trans-Urals, chariot, Sintashta and Petrovka burials, journey of the soul, Ashwins.

\section{REFERENCES}

Chechushkov I.V. (2011). Chariots of Eurasian steppes of Bronze Age. Vestnik arheologii, antropologii i etnografii, (2), 57-65. (Rus.).

Chechushkov I.V., Epimakhov A.V., (2010). Kolesnichny complex of Ural-Kazakhstan steppes. In: Koni, kolesnicy i kolesnichie stepej Evrazii (pp. 182-230). Ekaterinburg; Samara; Doneczk. (Rus.).

Gening V.F., Zdanovich G.B., Gening V.V. (1992). Sintashta: Archaeological monuments of Aryan tribes of Ural-Kazakhstan steppes. Vol. 1. Chelyabinsk: Yuzh.-Ural. kn. izd-vo. (Rus.).

Epimakhov A.V. (2002). Southern Trans-Ural in the Medium Bronze Age. Chelyabinsk: Izd-vo YuUrGU. (Rus.).

Izbicer E.V. (1993). Burials with carts of steppe strip of Eastern Europe and North Caucasus III-II thousand up to $B C$. Avtoreferat dis. ... kandidata istoricheskix nauk. St. Petersburg. (Rus.).

Littauer M.A. \& Crouwel J.H. (1996). The origin of the true chariot. Antiquity, 270.

Kostyukov V.P., Epimakhov A.V., Nelin D.V. (1995). New Monument of Middle Bronze in Southern Trans-Ural. In: Drevnie indoiranskie kul'tury Volgo-Ural'ya (II tys. do n.e.) (pp. 156-207). Samara: Izd-vo Samarskogo GPU. (Rus.).

Kuz'mina E.E. (1986). The oldest pastoralists from the Ural to Tian Shan. Frunze: llim. (Rus.).

Kuz'mina E.E. (2000). Horses and chariots of the Southern Ural and Indo-European myths. In: Problemy izucheniya eneolita i bronzovogo veka Yuzhnogo Urala (pp. 3-9). Orsk: In-t Evrazijskix issled.: In-t stepi UrO RAN. (Rus.).

Parpola A. (2015). The Roots of Hinduism. The Early Aryans and the Indus Civilization. Oxford University press.

Stefanov V.I., Epimakhov A.B. (2006). Sintashta III (small) mound: Some details and new stories. In: Voprosy arkheologii Povolzh'ya. Vyp. 4 (pp. 263-272). Samara: Nauchno-tekhnicheskij centr. (Rus.).

Tkachev V.V. (2003). Burial of the archaic leader of the Late Bronze Age from the grave of llekshar I in West Kazakhstan. In: Voprosy istorii i arkheologii Zapadnogo Kazaxstana. Vyp. 2 (pp. 80-88). Ural'sk: ZapadnoKazakhstanskij centr istorii i arkheologii: Institut istorii im. A.X. Margulana. (Rus.).

Vinogradov N.B. (2003). Bronze Age Grave Krivoe Ozero in South Trans-Ural. Chelyabinsk: Yuzh.-Ural. kn. izd-vo. (Rus.).

Vinogradov N.B. (2011). Steppes of Southern Trans-Ural and Kazakhstan in the first centuries of II thousand BC: (Sites of Sintashta and Petrovka type). Chelyabinsk: ABRIS. (Rus.).

Vinogradov N.B., Degtyareva A.D., Kuzminykh S.V., Medvedeva P.S. (2017). Images of an era: Bronze Age grave Krivoe Ozero in South Trans-Ural. Chelyabinsk: ABRIS. (Rus.).

Zdanovich D.G., Kupriyanova E.V. (2008). Paired horse sacrifices in the Bronze Age in Central Eurasia: Archaeology, mythology and ritual. In: Proisxozhdenie i rasprostranenie kolesnichestva (pp. 188-197). Lugansk: Globus. (Rus.).

Н.Б. Виноградов, https://orcid.org/0000-0002-0434-6012

\section{$(\mathrm{cc}) \overline{\mathrm{EY}}$}

This work is licensed under a Creative Commons Attribution 4.0 License. Accepted: 02.03.2020

Article is published: 05.06.2020 